\title{
産業用コンベヤベルトと技術動向
}

\author{
小林 英 治*.宮島純
}

\section{Conveyor Belts for Industry and the Recent Trend of Technologies}

Eiji KOBAYASHI* and Atsushi MIYAJIMA (Yokohama Rubber Co., Ltd. 2-1 Oiwake, Hiratsuka Kanagawa 254-8601, Japan) "eiji.kobayashi@y-yokohama.com

Conveyor belts are widely used in various industrial fields as a means of conveying things that can not be carried by human power and efficiently conveying them to a remote place.

A conveyor belt is designed with appropriate material, thickness, width and length according to the conveyance conditions, and in particular, the material of the cover rubber greatly affects the life of the belt. Therefore, depending on the properties of the material to be conveyed and chute conditions, the rubber for the abrasion resistance or heat resistance or oil resistance is selected.

In recent years, in addition to the basic performance required for conveyor belts, conveyor belts that take environmental or safety into consideration have been required(e.g. Low-Rolling-Resistant, Flame-Resistant).

In this report, we introduce these products and technologies.

(Received on May 31, 2017)

Key Words : Conveyor, Belt, Low-Rolling-Resistance, Flame-Resistant, Recycled Raw Materials

\section{1. 産業用コンベヤベルトとその基本性能}

コンベヤベルトは，人力では運べない物・場所において 運搬物を効率よく連続的に搬送する手段として, 各種産業 分野で広く活用されており（図1），2015年度の国内コン ベヤベルトの全需は（推定）240万 $\mathrm{m} に$ 及んでいる.

コンベヤベルトは，ポリエステルやナイロンを素材とす る帆布を補強材（芯体）とした帆布ベルト（図2（a)）と， スチールコードを補強材としたスチールコードベルト（図 2 (b)）とに分類され, 補強材との接着性を高めたコート

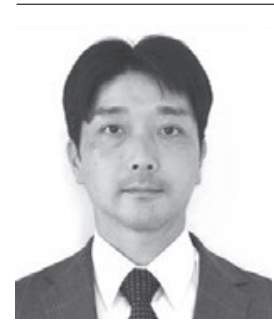

小林 英治；横浜ゴム(株) 工業資材事業部 工業資材技術部 開発1グループ（テ254-8601 神奈川県平塚市追分 2-1）課長. 平成 8年, 千 葉大学大学院工学研究科機械工学専攻 卒業. 同年, 横浜ゴム侏に久社 現在に至る。専門 は, 機械工学, 計算工学. 日本ベルト工業会 技術委員会 副主查.
ゴムおよびクッションゴムと, 補強材を保護するカバーゴ ムとで構成されている。 また，搬送条件に合わせて，適切 な材料・厚み・幅・長さにより設計され, 使用する際は輪 状に接合する作業（エンドレス作業）が行われる.

搬送物と直接接触するカバーゴムの物性は, コンベヤベ ルトの寿命に影響を及ぼすため, 搬送物の種類やコンベヤ ライン条件（搬送物温度, 搬送速度, 搬送物の投入高さ） などにより適切なゴム材料を適用する必要がある，常温の 砂, 砂利, 石灰石, 鉄鉱石, 石炭などの搬送には, 天然ゴ ム $(\mathrm{NR})$, スチレンブタジエンゴム $(\mathrm{SBR})$ およびブタジ

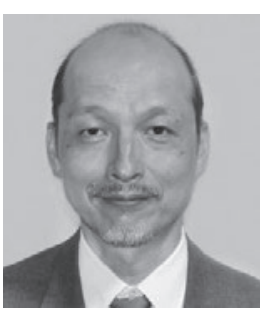

宮島 純 ; 横浜ゴム(株) 工業資材技術部開発 1 グループ（率254-8601 神奈川県平塚市追分 2-1） 課長補佐。平成 5 年, 中央大学理工学部 物理 学科卒業. 同年, 横浜ゴム(株)入社, 現在に至 る. 専門は, 物理学. 


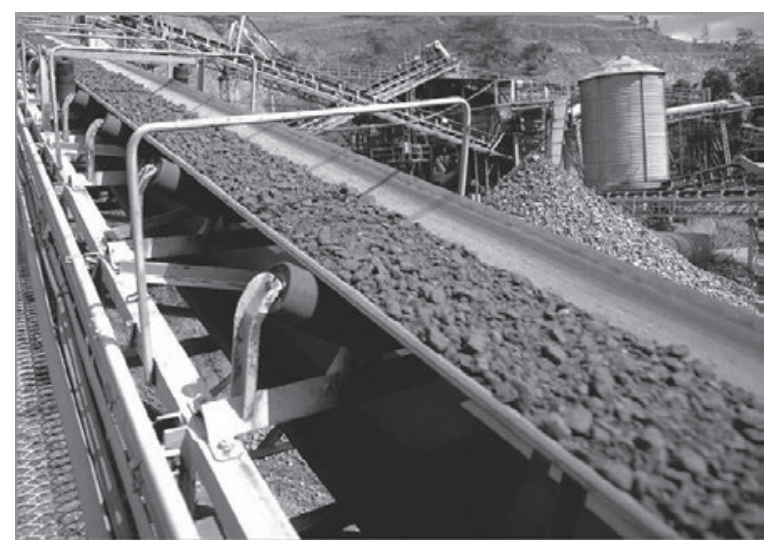

図1 コンベヤベルト使用例

カバーゴム

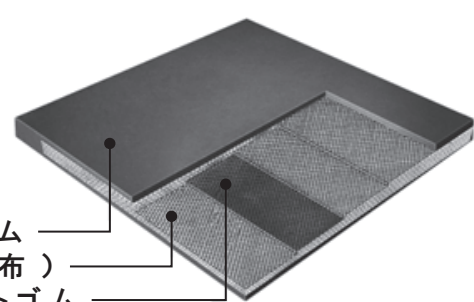

帆布層間コートゴム

（a）帆布ベルト

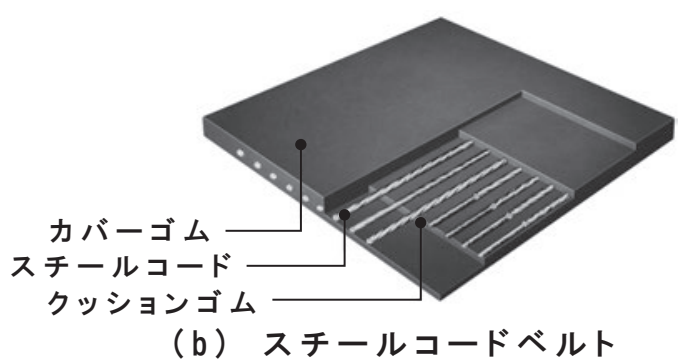

（b） スチールコードベルト

図2 コンベヤベルトの構造

表1 耐摩耗性帆布ベルトのゴムグレードと物性

\begin{tabular}{|c|c|c|c|c|c|c|c|}
\hline グレード & $\mathrm{P}$ & $\mathrm{G}$ & $\mathrm{S}$ & $\mathrm{A}$ & $\mathrm{L}$ & $\mathrm{D}$ & $\mathrm{H}$ \\
\hline 引張強さ & 8 & 12 & 18 & 14 & 15 & 18 & 24 \\
$(\mathrm{MPa})$ & 以上 & 以上 & 以上 & 以上 & 以上 & 以上 & 以上 \\
\hline 破断伸び & 300 & 350 & 450 & 400 & 350 & 400 & 450 \\
$(\%)$ & 以上 & 以上 & 以上 & 以上 & 以上 & 以上 & 以上 \\
\hline 摩耗值 & 400 & 250 & 200 & 150 & 200 & 100 & 120 \\
$\left(\mathrm{~mm}^{3}\right)$ & 以下 & 以下 & 以下 & 以下 & 以下 & 以下 & 以下 \\
\hline
\end{tabular}

エンゴム（BR）を主ポリマーとする耐摩耗性のカバーゴ ムが用いられる。表1は, JIS K 6322 「布層コンベヤゴム ベルト」に規定されているカバーゴムのグレードとその常 態物性の規格值である. カバーゴムは，一般的に搬送物を 載せる時に摩耗やカット, チッピングなどの物理的な損傷 を受けるため，搬送条件に適した引張強さ，破断伸び，摩 耗などのグレードが選定される.

たとえば，鉱石の採掘現場に近いコンベヤラインでは， 搬送物（鉱石）はクラッシャーである程度の大きさまでは 破砕されるものの, その大きさはこぶし台を超えるため, 質量も大きく，角が鋭利であるため，コンベヤベルトに対 する負荷が高い. したがって, 引張強さ (TS : Tensile Strength), 破断強度（EB : Elongation at Break）が大き
く，破断エネルギーの高い $\mathrm{H}$ グレードが用いられることが 多い.一方, 細かく粉砕された石炭や鉄鉱石, 砂利, 砂な どの搬送では, カバーゴムへの鉛直方向の衝撃エネルギー

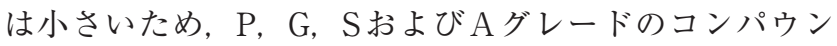
ドが, 必要とされる期待寿命とコストなどを考慮して最適 なグレードが用いられる。

また，特殊な搬送物を搬送するためのコンベヤべルトも 産業分野では数多く使用されている. 代表例として, コー クスや焼結鉱など高温物の搬送には耐熱性のベルトが用い られている. $100{ }^{\circ} \mathrm{C}$ 前後の低中温領域ではSBRを主ポリ マーとしたゴムが用いられ，それ以上の温度域ではエチレ ンプロピレンゴム（EPR）を過酸化物によって加硫した熱 老化を抑制した高温耐熱用コンパウンドが用いられてい る.

また，穀物や飼料の搬送やゴミ処理場などでは搬送物の 油分によるゴムの膨潤を抑えるためニトリルゴム（NBR） を主ポリマーとする耐油性のベルトが用いられている.

しかし，近年では，このようなコンベヤベルトに求めら れる基本的な性能に加え, 環境や安全に配慮したコンベヤ ベルトが求められるようになってきている.

\section{2. 環境対応型コンベヤベルト}

\section{1 省電カコンベヤベルト}

近年では, 夕イヤの転がり抵抗が自動車の燃費性能に寄 与することが知られており, それが夕イヤの基本性能のひ とつになっている. コンベヤベルトにおいても環境負荷低 減のため運転電力を低減し, 省電力化する製品が開発され ている.

図 3 はベルトコンベヤ装置の基本構成である.コンベヤ ベルトは, それに予張力を与え, プーリに押し付けること で摩擦力を高めた上で駆動プーリを回転させることによっ て駆動される.

省電力ベルトは, ベルトがアイドラーローラを通過する
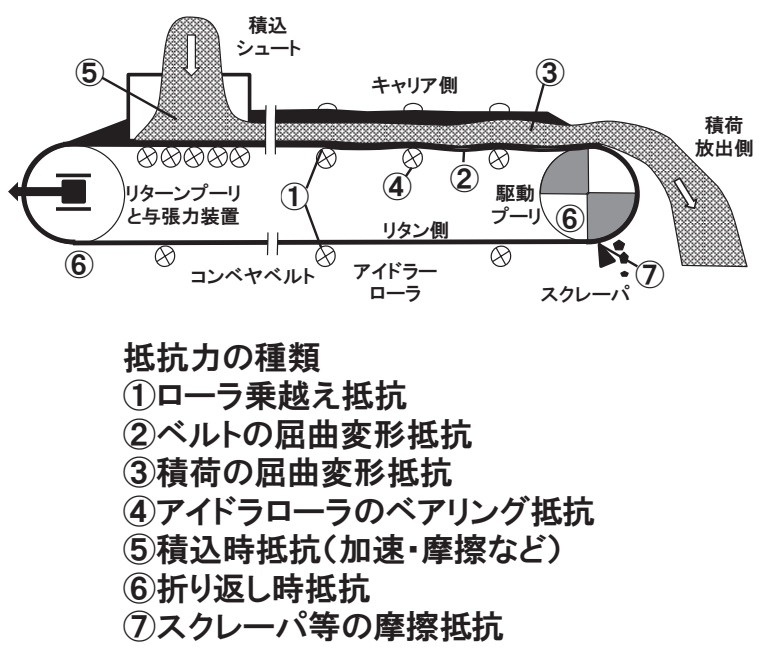

図 3 ベルトコンベヤ装置と抵抗力の概略図 
際の乗越え抵抗を減らしたものである。というのも，ロー ラ乗越え抵抗はベルトコンベヤにおいて比較的大きな抵抗 要因だからである.

ここではコンベヤベルトを運転するときの抵抗力の種類 とその内訳，および，運転電力を低減させるためゴム材料 に求められる特性について述べる.

ここで駆動プーリは搬送物放出側（ヘッド側）に設置さ れた構成を示しているが, 駆動力を要する長距離ライン や，高いところに積荷を持ち上げる必要があるラインでは 複数の駆動プーリを用いる場合もある。コンベヤ上側（キ ヤリア側）には，二本または三本で 1 セットとなるアイド ラーローラが一般に $1 \sim 2 \mathrm{~m}$ 程度の間隔で設置されてお り，搬送物が落ちないようにトラフ形状（V字型あるいは コップの縦断面のような形）を保持したまま積荷を積載側 から放出側まで搬送するようになっている.

コンベヤベルト走行中は, 図3に示す(1)～(7)の抵抗力が 発生している．実際には高低差による定常的な抵抗力（あ るいは推進力）が発生するが，ここではそれを無視できる 水平ラインについて抵抗力を次のようにまとめると，図 4 のような内訳になることがHagerらによって示されてい る $^{1)}$.

1. ローラ乗越え抵抗

2. 運搬中のベルト変形による抵抗力

3. 運搬中の積荷自体の変形による抵抗力

4. ローラについているベアリングの回転抵抗力

5. 二次抵抗力（荷積みでの加速やプーリ通過時のベルト 屈曲・スクレーパによる摩擦抵抗力など)

この内訳から分かるように，ローラ乗越え抵抗を小さく することは，コンベヤベルト装置全体の走行抵抗を小さく することに効果的である。 また，ローラ乗越え抵抗はべル トのゴムによって改善可能で，実際に改善したものが省電 カベルトとして販売されている.

省電力ベルトは，ローラと接触する下面カバーゴムの変 形と粘弾性によるエネルギーロス（ $\left.\tan \delta, \mathrm{E}^{\prime \prime}\right)$ を小さくし,

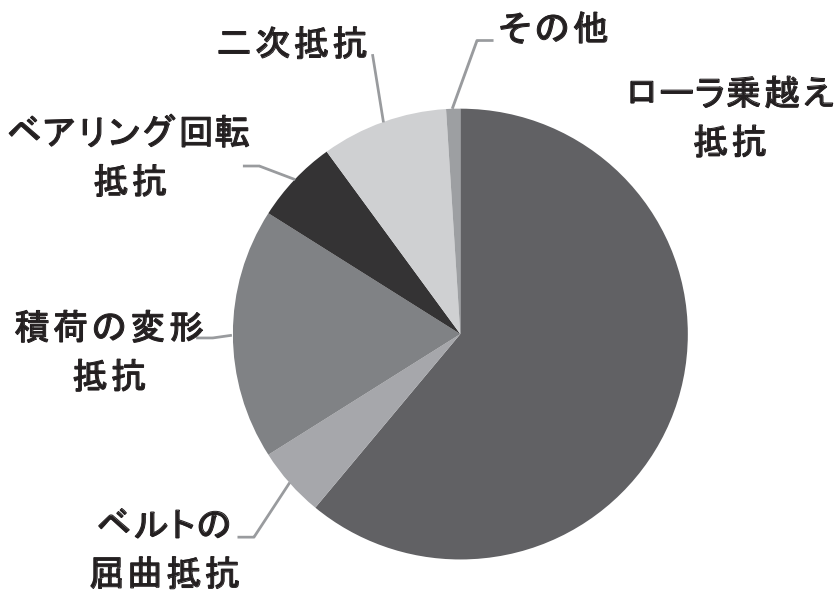

図4 ベルトコンベヤの抵抗力内訳
個々のローラ乗越え抵抗を抑えたもので，ローラ数が多い 場合ほど電力削減効果は高い。つまり, ベルトを支持する ためのローラが多く必要になる長距離ラインほど効果的で ある。

例えば, 水平 $1 \mathrm{~km}$ のベルトコンベヤでは, 図4のとお りローラ乗越え抵抗は全体の約 6 割を占めるが，この抵抗 力を半減できたとすると，全体の抵抗力は通常より $30 \%$ 低減することができる。

国内では，鉱山部から平地・港湾部へ，つまり高いとこ ろから低いところへの搬送となるケースが多く，位置エネ ルギーによってベルトを進めようとする力が働くので，走 行抵抗の殆どがコンベヤベルトのローラ乗越え抵抗である とみなせる場合もある。このようなラインでは省電力ベル トの効果が大きく発揮され, 従来の耐摩耗系ゴムを用いた ベルトに比べて半分以下の電力で運転できる場合や, 設備 次第では発電できる場合さえある。一方, 登りの場合はこ こで示した全抵抗力と同程度の積荷を持ち上げるための工 ネルギーが必要になるため, 水平ラインと同じようにロー ラ乗越え抵抗を改善できたとしても, 全体の抵抗力が大き いので同機長の水平または下りラインに比べると効果が小 さく見えてしまう，従って，省電力ベルトの評価には注意 が必要である。

次に，ローラ乗越え抵抗について概観する。乗越え抵抗 力についてはJonkersによって基礎的な抵抗力の議論がな されている ${ }^{2)}$. 図 5 は, ローラ上のベルトの変形の概略図 である。ローラ上を通過中のコンベヤベルト下面は, ベル 卜上部にある積荷とベルト自重による荷重でローラに押し 付けられるので，下面カバーゴムはローラが食い込んだよ うに変形する。このときベルトは左から右へ移動している

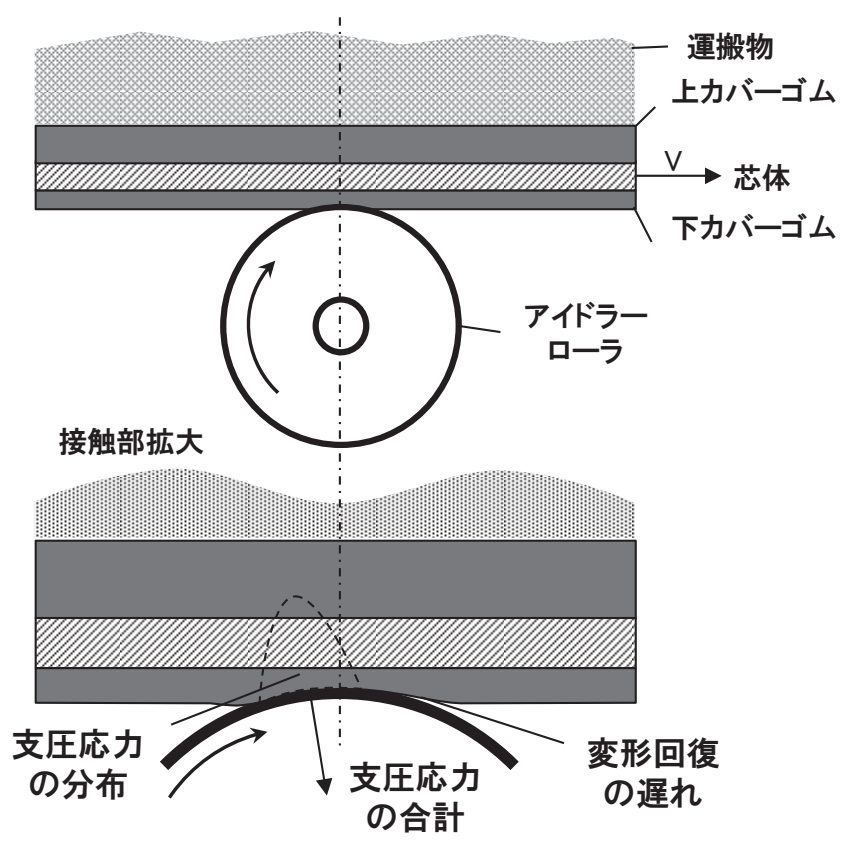

図５ローラ上のベルトの変形の概略図 
のでゴムの変形は動的に進行する。

下面カバーゴムの変形現象を接触が始まり接触圧が上昇 していくローラ左半分と, 減少していく右半分に大まかに 分けると, 左側は接触圧が上昇し変形は遅れて追従する. 一方, 右側では接触が解かれるが既に変形している状態か ら回復しようとするが, 変形の遅れから左側よりはローラ を押さえつける圧力が小さくなる，両側の状態を合わせる と, 接触圧力の分布は左右非対称で, 左側に偏った分布に なる。

この接触圧の合力は，ローラに斜め下方向に向かう支圧 応力となる. 支圧応力の水平成分がベルト通過時の抵抗 力，すなわちローラ乗越え抵抗となるのである。

つまり，コンベヤベルトのローラ乗越え抵抗は，ゴムに 荷重を加えて変形させるとき, 応力の発生が先行し．ひず みが遅れてくるという，ゴムの粘弾性現象そのものによっ て発生する. ベルトの場合の接触圧とひずみを応力ーひず み平面に表すと図6のようになる。このようにコンベヤべ ルトはアイドラーローラによって変形ー回復を繰り返す過 程でヒステリシスロスによる発熱を生じるので，これを低 く抑えることがローラ乗越え抵抗低減に対する基本的方針 である，従って，省電力ベルトに用いるゴムは，変形によ るヒステリシスロスよる発熱を抑えた特性が要求されるの で，低発熱性のゴムが望ましく，タイヤで言うとアンダー トレッドゴムや，サイドウォールのような低発熱ゴム配合 が望ましい，文献による様々なポリマー系ベルトの走行抵 抗測定によると, NR/BR系, NR系, SBR系, NR/SBR 系， CR， NBRの順にローラ乗越え抵抗が高くなっている 3).
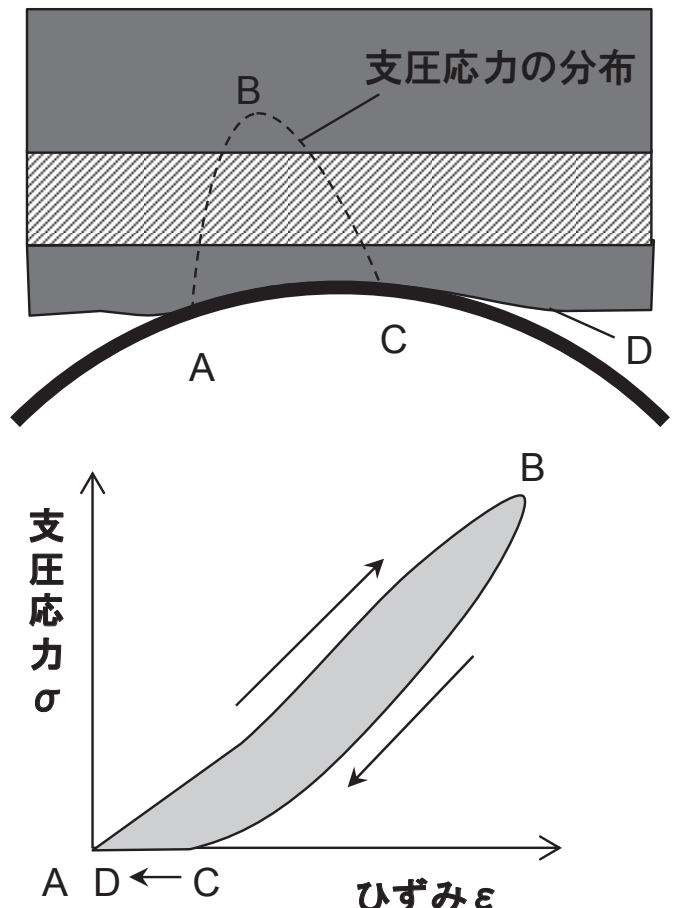

図6 ローラ乗り越え時の応力-ひずみのヒステリシスループ

\section{2 耐付着性コンベヤベルト}

コンベヤベルトを使用するうえで，多くのユーザーで落 鉱が問題となっている。落鉱とは, 本来はコンベヤライン のヘッド側で搬送物を全量放出するのが理想であるが，表 面に付着した搬送物がリターン側で落ち，コンベヤライン の下に堆積していく現象である.

これを防止するため，設備側ではべルト反転装置を用い てリターン側もベルトの搬送面を上側にしたり，ベルトを 丸めてパイプ状にしたりすることもあるが，これらの設備 を用いるとコンベヤベルトを捻る必要があるため, コンベ ヤベルトに過大なストレスがかからないようにする距離が 必要となる。従って, 機長の短いコンベヤラインではこの ような方法は取ることができないので，そのようなコンべ ヤラインではヘッドプーリー付近に取り付けられたスクレ ーパでできる限りベルト表面から搬送物を取り除くように するが，スクレーパをベルト表面に強く当てすぎるとカバ ーゴムの摩耗を加速させることになるため, 完全に除去す ることは困難である。その結果，コンベヤラインの下には 搬送物が堆積し, その除去に労力が掛かるとともに, 周囲 環境を徳化させることとなる．

そこで，コンベヤベルトのカバーゴムに耐付着性を持た せた製品も開発されており，ベルトへの付着性が高い水分 を含んだ鉄鉱石や石炭, 鋳物砂などを搬送するコンベヤラ インでの使用が広まっている.

ゴムに耐付着性を発現させる手法としては，不飽和脂肪 酸金属塩やポリエチレンなどの樹脂を配合することなどが 挙げられ，それにより表面の平滑性を確保したり，撥水性 を高めたりしている。

図7に，弊社独自の評価方法を用いて耐付着性ゴムと一 般耐摩性ゴムについて，水分率 $10 \%$ の鋳物砂の付着量を 比較した結果を示す。これによると, 耐付着性ゴムへの付 着量は耐摩耗性ゴムの 20 分の 1 であり, 実際のコンベヤラ インでも耐付着性ベルトに切り替えたことで，落鉱が大幅 に減少し，大きな効果を上げている.

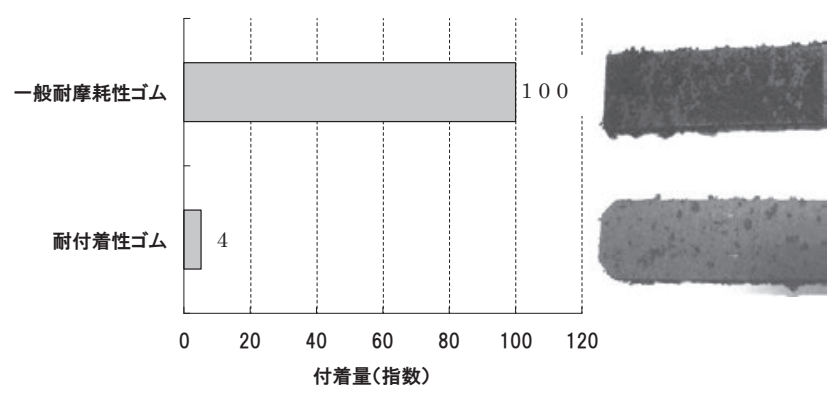

図7 付着性比較（搬送物：鋳物砂・水分率 $10 \%)$ 


\section{3. 難 燃性ベルト}

コンベヤベルトの火災は古くから度々発生しており， ユ ーザーにおける操業停止による損失のみならず，地域環境 へも影響を及ぼすこととなる。炎の原因は様々であり， 石炭など搬送物の発熱によるもの，アイドラーローラの破 損によるローラ不回転やコンベヤベルト蛇行により設備フ レームへの接触などコンベヤ設備とコンベヤベルトとの摩 擦熱によるもの，などメカニズムは様々である。 それらに 対して, ユーザー側ではコンベヤライン改善や保全の強化 を, ベルトメーカー側ではコンベヤベルトの難燃化などの 対策を講じている.

難燃性コンベヤベルトは, 一般的には, 耐摩耗性ベルト をベース配合として，それにハロゲン系配合剤を添加する ことが一般的であるが，主ポリマーをクロロプレンゴム （CR）とすることで難燃性を確保することもある。それら のゴムは, 燃焼時に不燃性ガスを発生させ, 酸素を遮断 し，酸欠状態にすることで自己消火させる．また，代表的 なハロゲン系難燃剤として, 塩素化パラフィン, デカブロ モジフェニルェタン（DBDE）などが挙げられる，以前は $\lceil\mathrm{DBDE} 」$ というと, デカブロモジフェニルエーテルであ つたが，環境規制のため現在では代替品であるデカブロモ ジフェニルエタンを指す。また，三酸化アンチモンをこれ らの難燃剤と併用することで難燃性能を高めたり，アフタ ーグローを抑えるため水酸化アルミなどを添加することも 一般的な手法として知られている。 なお，アフターグロ 一とは，炎が消えたあとにサンプル内に残る赤熱部（残 火）のことである.このように, 難燃化の手法はいくつか あるが，コストや物性，難燃性の要求に応じて，最適な配

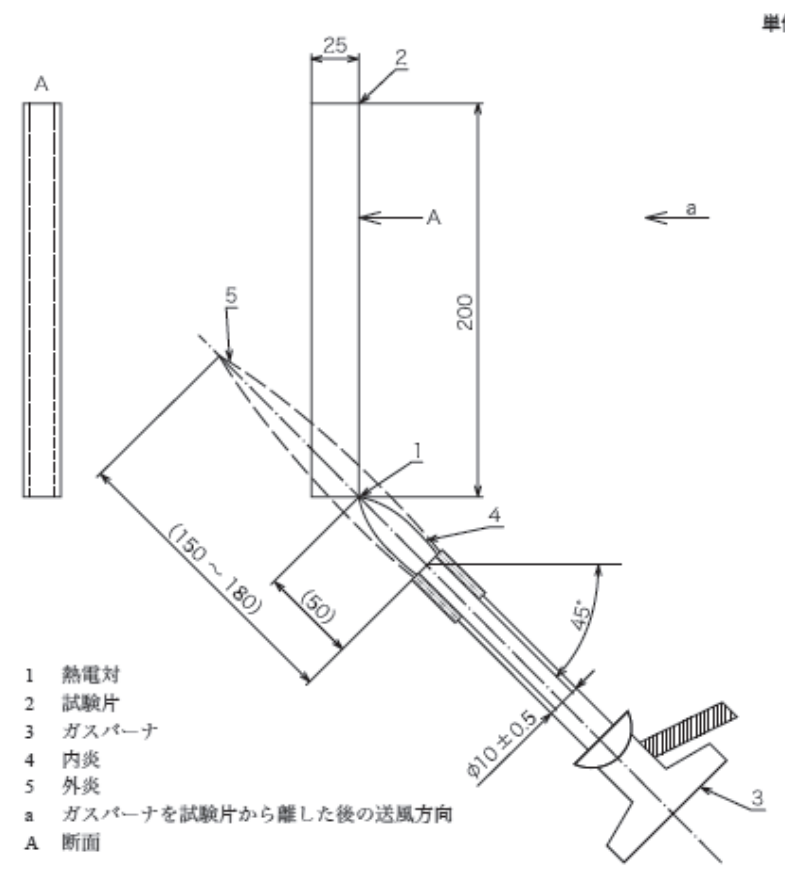

図 8 JIS K $6324: 2013$ 燃焼試験方法
合手法が用いられている。

また, 難燃性の要求としては, JIS K 6324 「難燃性コン ベヤゴムベルト - 等級及び試験方法」によりその等級が規 定されている。図 8 は, 同規格で規定されている燃焼試験 方法であり, 図9 は, 難燃性ベルトの燃焼試験の様子であ る.また，表 2 は難燃性の等級とその要求性能である.

国内では，設備側の対策により火災のリスクが低減され ているが, より安全性を高めるうえで難然性等級が 3 級相 当の難燃性ベルトが比較的広く使用されている.

一方, 操業上, 重要なコンベヤラインや, より高い安全 性が要求されるコンベヤラインでは, さらに難燃性を高め た 1 級または 2 級のコンベヤベルトが使用されることもあ る.しかし，難燃性能を高めるためには，カバーゴムへの 難燃剤の多量配合, コートゴムや芯体の難燃化が必要なた め, 一般的にはベルトとしてのコストが高くなる．従っ て, 安全性とコストとのバランスを加味して難燃性の等級 を選択する必要があるが, 近年ではユーザーにおける安全 性へのウェイも高まりつつある.

\section{4. ベルトメーカーとしての環境への取り組み ${ }^{4)}$}

ここまでは使用時における環境および安全に配慮したコ ンベヤベルトについて述べてきたが, 経済産業省が推進す る3R活動 (Reduce・Reuse ・ Recycle) を積極的に取り組 むこともべルトメーカーにも求められている.

古くから夕イヤなどゴム製品からリサイクルした再生ゴ ムは各種ゴム製品に使用されてきたが, 再生ゴムの配合に よりゴム物性の低下を招くため, 要求性能の低い分野が主

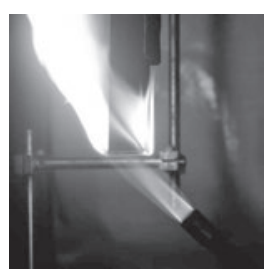

(a) 燃焼 中

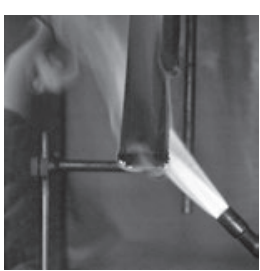

(b) 炎を外した直後 図9 燃焼試験の様子

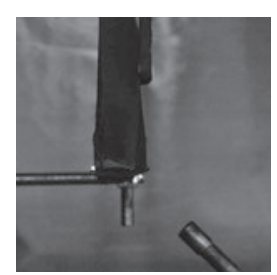

(c) 送風 1 分後
表 2 難燃等級と要求性能

\begin{tabular}{|c|c|c|c|}
\hline \multirow{2}{*}{ 項目 } & \multicolumn{3}{|c|}{ 難燃性の等級 } \\
\hline & 1 級 & 2級 & 3級 \\
\hline カバーゴム付き & $\begin{array}{ll}\text { 長さ方向 } & 3 \text { 個 } \\
\text { 幅方向 } & 3 \text { 個 } \\
\end{array}$ & \begin{tabular}{|ll} 
長さ方向 & 3 個 \\
幅方向 & 3 個 \\
\end{tabular} & 長さ方向 3個 \\
\hline カバーゴム無し & $\begin{array}{ll}\text { 長さ方向 } & 3 \text { 個 } \\
\text { 幅方向 } & 3 \text { 個 } \\
\end{array}$ & - & - \\
\hline 炎の持続時間 & $\begin{array}{l}\text { カバーゴム付き } \\
\text { 及びカバーゴム } \\
\text { 無し各々の試験 } \\
\text { 片 } 6 \text { 個の炎の持 } \\
\text { 続時間の合計が } \\
45 \text { 秒未満. かつ, } \\
\text { 個々の炎の持続 } \\
\text { 時間は最大 } 15 \text { 秒 } \\
\text { を超えない. }\end{array}$ & $\begin{array}{l}\text { 試験片 } 6 \text { 個の炎 } \\
\text { の持続時間の合 } \\
\text { 計が } 45 \text { 秒未満. } \\
\text { かつ, 個々の炎 } \\
\text { の持続時間は最 } \\
\text { 大15秒を超えな } \\
\text { い. }\end{array}$ & $\begin{array}{l}\text { 試 験片 } 3 \text { 個 の } \\
\text { 個々の炎の持続 } \\
\text { 時間が } 60 \text { 秒を超 } \\
\text { えない. }\end{array}$ \\
\hline 再燃性 & すべての試験片l & こついて, 炎が耳 & してはなら \\
\hline
\end{tabular}




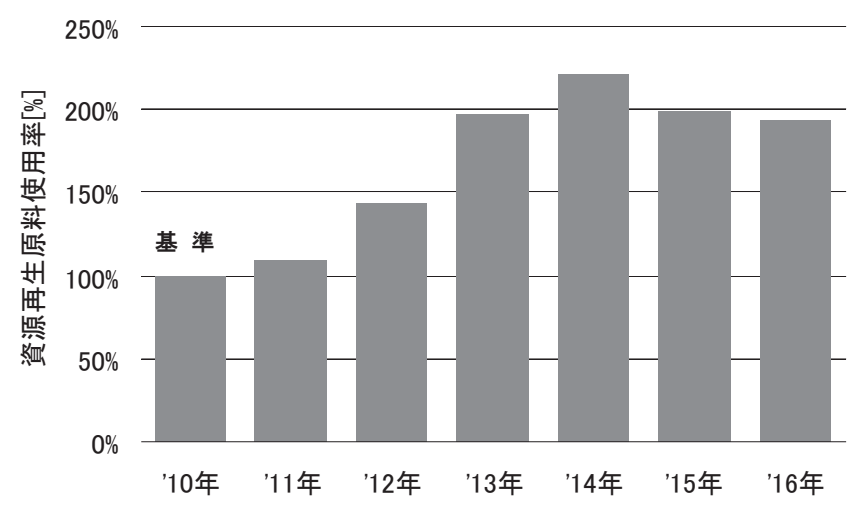

図 10 資源再生原料使用量推移（横浜ゴム(株非夕イヤ部門）

に利用されてきた。しかし，近年では，再生ゴムの品質も 向上しており，安定した性能を維持することができるよう になってきているとともに, 配合技術の向上から産業用コ ンベヤベルトへの適用も増加している，具体的には，比較 的シビアリティの低い, 砕石, セメント, 木材チップ, 石 灰などの各種バラ物搬送に適した一般用途向けのコンベヤ ベルトへの再生ゴムの適用が進んでいる.

前述のとおり，一般的にゴムに資源再生原料を高配合化 すると各種物性が低下することが知られているが，ポリマ 一, カーボンブラックおよび配合剤の種類とその配合量の 最適化により従来のゴムと同等以上の物理性能を実現する ことができている，その結果，各部材への資源再生原料の 配合量は, 当社従来品に比べて上面カバーゴムが $0 \%$ から $12 \%$ ， 下面カバーゴムが $0 \%$ から $11 \%$ ，コートゴムが $20.8 \%$ から $22.3 \%$, それぞれ増加し, 開発以前に比べて 再生ゴムの使用量は2 倍となっている（図 10）.

さらに，当社はタイヤメーカーとして乗用車用タイヤか ら大型の建機用タイヤまで国内外で製造・販売している. そのなかでトラック・バス用タイヤは天然ゴムを主原料と する材料を多く使用しているため, 資源再生原料の材料と して利用されている。 それらトラック・バス用タイヤの一
部はリトレッド会社にて回収され，タイヤ構造体として使 用可能な中古タイヤはトレッドゴム（地面に接するゴム） を除去し，新たなトレッドゴムを加硫接着させ，更正タイ ヤとして販売している.

一方, 回収されたタイヤのなかで更正タイヤとして使用 不可能なタイヤやユーザーが直接廃裹する夕イヤは, 廃夕 イヤ回収業者に引き取られる。 これらのタイヤの利用方法 としては, (1)再生原料メーカーに買い取られて再生原料に 加工されるもの, (2)ボイラーなどの燃料として利用される もの（サーマルリサイクル），(3)粉砕やサーマルリサイク ルおよび再生原料に加工される過程で発生するカーボンや 鉄などの原料として回収されるもの（マテリアルリサイク ル）、などが挙げられる。 そして，ここで再生された原料 をコンベヤベルトなどのゴム製品へ使用するサイクルを積 極的に取り入れ，資源循環システムを構築することでコン ベヤベルトメーカーとしても環境負荷低減に努めている.

\section{5. ま と め}

コンベヤベルトは幅広い産業分野で活用され，長寿命・ 安定操業という基本的なニーズに応えるべく用途に合わ せ, 多種多様なゴム材料が用いられている。近年では, こ れらの基本性能に加え, 安全性や環境への要求も高まりつ つあり, ベルトメーカー各社ともそれらに対応した技術開 発を進めている，今後も，これまでと異なる搬送物や搬送 条件など新たなニーズが出てくる可能性もあり, それに応 じたゴム材料の開発も必要になっていくと考えられる.

\section{Reference}

1 ) Hager, M; Hintz, A.: Bulk solids handling, 13, 749 (1993)

2 ) Jonkers, C.O.: Förden und Heben, 30, 312 (1980)

3 ) Lauhoff, H.: Bulk solids handling, 25, 368 (2005)

4) Kobayashi, E.: Kankyou Kanri, 52, 48 (2016)

\section{日本語表記参考文献}

4 ）小林英治：環境管理， 52，48（2016） 